\title{
PENGEMBANGAN PERAN PEREMPUAN PESISIR
}

\author{
(Analisis Kualitas Sumber Daya Pada Perempuan Muda)
}

\author{
Oleh: \\ NOVLIZA EKA PATRISIA, LINDA SAFITRA \\ Program Studi Ilmu Administrasi Publik Fakultas Ilmu Sosial dan Ilmu Politik \\ Universitas Muhammadiyah Bengkulu
}

\begin{abstract}
The phenomenon of coastal community life is always characterized by poverty and helplessness. The fishing community as a relatively dominant feature of the coastal community is often overwhelmed by unstable economic problems. This situation is very fantastic and contradictory, because the natural conditions that have the potential and abundant natural resources. The focus of this research is on the role of women who have a role as housewife and also as manager and marketing of catch fish from men. This study uses qualitative analysis which aims to reveal the problems that exist as detailed as possible on the condition of young coastal women with data collection techniques using observation, interview and documentation. The result of this research is the ability and role of young woman is still low, just as fish seller only without doing any recondition again also not accommodate potential area that can be cultivated become income source, impressed not creative managing potency, have pragmatic thinking and minimal skill and leads to consumptive behavior. Cultures and values built across generations of women emphasize the role of women in support of husbands but have not developed logical mechanization that creativity, knowledge and expertise are essential to building a prosperous family. The systems and networks of existing programs related to the development of women are numerous but have no coherence to the development goals and their usefulness. Here it is necessary to sharpen all systems and values so that dynamic changes are needed to change the existing conditions.
\end{abstract}

Keywords: culture, poverty, young women, value system.

\section{PENDAHULUAN}

Secara konseptual, pemberdayaan atau pemberkuasaan (empowerment), berasal dari kata power yang berarti kekuasaan atau keberdayaan. Konsep pemberdayaan berawal dari penguatan modal sosial di masyarakat (kelompok) yang meliputi penguatan modal sosial, kepercayaan (trust), patuh aturan (role), dan jaringan (net working). Apabila kita sudah memiliki modal sosial yang kuat maka kita akan mudah mengarahkan dan mengatur (direct) masyarakat serta mudah mentransfer pengetahuan kepada masyarakat dan dapat menguatkan pengetahuan, modal (money), dan masyarakat. Konsep ini mengandung arti bahwa pemberdayaan masyarakat adalah transfer kekuasaan melalui penguatan modal social kelompok untuk menjadikan kelompok produktif untuk mencapai kesejahteraan sosial. Modal sosial yang kuat akan menjamin keberlanjutan didalam membangun rasa kepercayaan di dalam masyarakat 
khususnya anggota kelompok (how to build thr trust). Oleh karena itu, ide utama pemberdayaan bersentuhan dengan konsep mengenai modal sosial dan kekuasaan. Kekuasaan sering kali dikaitkan dan dihubungkan dengan kemampuan individu untuk membuat individu melakukan apa yang diinginkan, terlepas dari keinginan dan minat mereka.

Pada dasarnya, pemberdayaan diletakkan pada kekuatan tingkat individu dan sosial (Sipahelut, 2010). Jimmu (2008) menyatakan bahwa pengembangan masyarakat tidak hanya sebatas teori tentang bagaimana mengembangkan daerah pedesaan tetapi memiliki arti yang kemungkinan perkembangan di tingkat masyarakat. Pembangunan masyarakat seharusnya mencerminkan tindakan masyarakat dan kesadaran atas identitas diri. Oleh karena itu, komitmen untuk pengembangan masyarakat harus mengenali keterkaitan antara individu dan masyarakat dimana mereka berada. Masyarakat adalah sebuah fenomena struktural dan bahwa sifat structural dari kelompok atau masyarakat memiliki efek pada cara orang bertindak, merasa dan berpikir. Tapi ketika kita melihat struktur tersebut, mereka jelas tidak seperti kualitas fisik dari dunia luar. Mereka bergantung pada keteraturan reproduksi sosial, masyarakat yang hanya memiliki efek pada orang-orang sejauh struktur diproduksi dan direproduksi dalam apa yang orang lakukan. Oleh karena itu pengembangan masyarakat memiliki epistemologis logis dan yang dasar dalam kewajiban sosial yang individu memiliki terhadap masyarakat yang mengembangkan bakat mereka. Konsep pemberdayaan perempuan pada dasarnya merupakan paradigm baru pembangunan yang lebih mengasentuasikan sifat-sifat "people centered, participatory empowering sustainable". Walaupun pengertiannya berbeda namun tetap mempunyai tujuan yang sama. Yaitu untuk membangun daya, dengan mendorong, memotivasi, dan membangkitkan kesadaranakan potensi yang dimilikinya, serta daya upaya mengembangkan kearah yang lebih baik.

Ini berarti perempuan tidak lagi hanya berperan sebagai ibu rumah tangga yang menjalankan fungsi reproduksi, mengurus anak dan suami atau pekerjaan domestik lainnya, tetapi sudah aktif berperan di berbagai bidang kehidupan, baik sosial, ekonomi maupun politik. Hal ini dimungkinkan karena adanya persamaan gender, persamaan intergenerasi, ditingkatkannya kehidupan berdemokrasi seiring dengan perkembangan jaman. Dalam proses pemberdayaan perempuan diperlukan perencanaan yang tersusun secara matang dan langkah selanjutnya adalah mobilisasi sumber daya yang diperlukan. Pada dasarnya penerapan nilainilai demokrasi pada program pemberdayaan perempuan sama dengan penerapan nilal-nilal demokrasi pada masyarakat umum, baik laki-laki maupun perempuan. Jadi pada intinya berupa dana (modal, sumber daya manusia, teknologi dan organisasi atau kelembagaan).

Strategi pemberdayaan dapat melalui pendekatan individual, kelompok atau kolektif dengan saling memberdayakan perempuan mitra sejajar pria dengan menggunakan pendekatan dua arah perempuan dan pria yang saling menghormati sebagai manusia, saling mendengar dan menghargai keinginan serta pendapat orang lain. Upaya saling memberdayakan ini meliputi usaha menyadarkan, mendukung, mendorong, dan membantu mengembangkan potensi yang terdapat pada diri individu, sehigga menjadi manusia mandiri tetapi tetap berkepribadian. Pemberdayaan perempuan dapat diartikan pula sebagai kemampuan untuk berpartisipasi dalam segala aspek kehidupan, sehingga dapat menyalurkan pendapatnya, mampu mengungkapkan kebutuhannya, dapat menganalisis dan turut serta dalam perencanaan, pelaksanaan dan monitoring evaluasi segala program yang berkaitan dengan dirinya.. 
Beberapa hasil penelitian yang terkait dan relevan dengan kajian ini adalah penelitian Maria E. Pandu dkk, (2014) menunjukkan bahwa ada beberapa kondisi yang dialami perempuan di Desa Baruga Kabupaten Bengkulu Tengah dan Desa Passimarannu Kabupaten Sinjai, yaitu tingkat pendidikan rendah, pekerjaan utama sebagai ibu rumah tangga saja, dan tidak mempunyai pekerjaan sampingan. Sementara potensi sumber daya alam yang dimiliki berupa rumput laut dan ikan. Namun sumber daya tersebut dikelola secara tunggal belum bervariasi sehingga pendapatan keluarga relative rendah. Potensi lainnya berupa jumlah sumber daya perempuan produktif lebih besar dari pada jumlah laki-laki. Namun, posisi perempuan dalam kehidupan ekonomi rumah tangga menunjukkan bahwa perempuan hanya terikat dengan aktivitas produksi suami yaitu kegiatan sebagai petani rumput laut dan nelayan. Faktor penghambat bagi keterlibatan perempuan pada sektor publik di luar rumah tangga antara lain selain; tingkat pendidikan rendah, tingkat keterampilan rendah, dan tidak ada modal.

Salah satu permasalahan menangani kemiskinan adalah kurang kesesuaiannya pandangan dan kondisi dasar pengertian, hal ini tidak bias disalahkan karena memang kemiskinan merupakan fenomena multi dimensi dan sangat rentan pengukuran dan kesimpulan yang dihasilkan (Nurwati, 2008). Strategi pemberdayaan yang tepat guna terhadap perempuan keluarga miskin di desa Baruga dan Desa Passimarannu dapat dimulai dari adanya kelompok orang dari luar kedua desa tersebut baik swasta maupun pemerintah yang menjadi pendorong untuk membuka wawasan, menyadarkan kondisi kehidupan mereka. Kemudian, dilanjutkan dengan kegiatan-kegiatan penyuluhan mengenai hal-hal yang berkaitan dengan kehidupan social ekonomi serta perlatihan-pelatihan keterampilan yang dibutuhkan dalam rangka meningkatkan pendapatan keluarga mereka.

Demikian pula hasil penelitian yang dilakukan oleh Wahyu Nugraheni S dkk, (2012) bahwa selain wanita nelayan berperan sebagai ibu rumah tangga (domestik), wanita nelayan di Desa Bedono juga berperan dan ikut berpartisipasi mencari nafkah untuk pemenuhan ekonomi keluarganya. Bias jender dalam kehidupan ekonomi keluarga sudah tampak kabur karena para istri juga dituntut untuk memenuhi kebutuhan keluarga. Partisipasi istri dalam meningkatkan kesejahteraan keluarga di desa Bedono diwujudkan dalam lingkunganrumahtangga, dalam bidang ekonomi, maupun dalam masyarakat.

\section{METODE PENELITIAN}

Penelitian ini menggunakan pendekatan kualitatif-eksploratif. Penentuan lokasi penelitian dengan menggunakan metode purposif, yaitu menentukan tempat penelitian berdasarkan tujuan khusus yang ditetapkan oleh peneliti. Lokasi penelitian dilaksanakan di Kampung Sejahtera Kecamatan Kampung Melayu Kota Bengkulu. Disain penelitian dengan teknik aksi partisipan, metode pengumpulan data yang penulis gunakan adalah : (1)Observasi, (2)dokumentasi, dan (3)Wawancara. Metode observasi merupakan metode yang dilakukan guna memperoleh data- data yang konkrit melalui pengamatan secara langsung dengan panca indra. Metode observasi yang digunakan dalam penelitian ini menggunakan observasi partisipan, dengan cara melihat kondisi lokasi langsung.

Metode dokumenter dalam penelitian ini mengambil data- data yang bersumber dari buku-buku, dokumen-dokumen dan arsip-arsip yang berkaitan dengan permasalahan. Selain berbagai dokumen tertulis yang dibutuhkan, digunakan juga 
alat dokumentasi yang dapat mendokumentasikan data berupa gambar dan rekaman suara. Pengumpulan data dilapangan, peneliti menggunakan metode wawancara mendalam, yang sifatnya terstruktur. Pelaksanaan wawancara tidak hanya sekali atau dua kali, melainkan berulang - ulang dengan maksud mendapatkan gambaran lengkap tentang topik yang diteliti. Peneliti dalam melakukan wawancara menggunakan alat bantu yaitu pedoman wawancara yang nantinya berfungsi untuk mengarahkan agar materi wawancara tidak keluar dari data yang digali oleh peneliti. Penelitian informan dalam penelitian ini menggunakan tehnik Snowball atau bola salju. Teknik wawancara yang digunakan untuk mengumpulkan informasi dari para informan adalah wawancara bebas mendalam. Para informan tersebut terdiri dari: tokoh masyarakat, perempuan muda pesisir, nelayan dan organisasi masyarakat.

\section{HASIL PENELITIAN DAN PEMBAHASAN}

Pada umumnya, masyarakat nelayan atau masyarakat pesisir di Kampung Sejahtera merupakan kelompok masyarakat yang relatif tertinggal secara ekonomi, sosial (khususnya dalam hal akses pendidikan), dan kultural. Proyeksi hasil sensus pendudukan berdasarkan tabel (terlampir), jumlah penduduk yang ada di wilayah Kecamatan Kampung Melayu pada tahun 2015 adalah 132.603 jiwa dengan penduduk laki - laki sejumlah 66.843 jiwa dan penduduk perempuan sejumlah 65.760 jiwa. Dalam tiga tahun terakhir terjadi penambahan penduduk di Kecamatan Kampung Melayu, hal ini dapat dilihat dari laju pertumbuhan penduduk pada tahun 2014 dari tahun 2013 mengalami pertambahan penduduk sejumlah 1.744 jiwa dari tahun 2013. Sedangkan pertambahan penduduk dari tahun 2014 ketahun 2015 sejumlah 589 jiwa. Adapun perbandingan jumlah penduduk laki-laki dan perempuan di kecamatan Kampung Melayu adalah 50,41 penduduk laki-laki dan 49,59 penduduk perempuan.

Dalam hal struktur sosial, baik secara langsung atau tidak langsung, Ada pelapisan social dalam kehidupan masyarakat Kampung Sejahtera. Pelapisan social ini antara lain, didasarkan kepada status agama, dan kekayaan seseorang. Karena status tergolong tinggi, seseorang akan disegani oleh warga masyarakat lainnya. Demikian pula, tingkat penggunaan agama dan kekayaan dapat menjadikan orang yang bersangkutan memiliki nilai tersendiri dalam masyarakat setempat. Orang yang paling disegani oleh masyarakat setempat adalah kyai, kyai adalah orang yang ahli dan memiliki pengetahuan luas tentang agama, khususnya agama islam. Masyarakat mengganggap bahwa kyai adalah panutan warga sekitar.

Setelah kyai, orang yang disegani oleh warga kampung sejahtera adalah "kerawat" atau "pamong" (aparat), kerawat dihormati oleh masyarakat karena kedudukannya. Seperti, guru dan orang kaya. Guru dianggap orang yang sangat berjasa dalam pendidikan anak-anak mereka, guru juga member teladan dan bimbingan, serta pembaruan dalam masyarakat. Orang kaya disegani oleh masyarakat sekitar karena materi (kekayaan) yang dimiliki. Dalam hal tertentu orang kaya adalah penolong bagi warga sekitar.

\section{Pola Pemukiman dan KeadaanFisik}

Pola pemukiman masyarakat terbentuk memanjang di sepanjang garis pesisir pantai. Selain itu juga memanjang mengikuti alur sepanjang sungai dan jalan. Bangunan rumah yang berada dipinggir 
jalan seluruhnya menghadap kejalan, sedangkan yang agak jauh dari jalan menghadap gang. Sepintas, tata letak bangunan rumah di kampung ini tampak teratur dan rapi. Akan tetapi, kesan itu akan pudar jika kita memasuki salah satu gang di kampung sejahtera ini. Karena letak bangunan yang tidak teratur atau searah, serta bentuk dan ukuran bangunan rumah yang tidak sama. Kenampakan yang cukup teratur hanya tampak dibagian pinggir jalan saja. Pemandangan yang semrawut dijumpai didalam perkampungan. kampung ini memiliki penduduk yang banyak dan daerah yang luas pula. Namun cenderung penduduk membangun pemukiman semakin rapat karena semakin banyaknya jumlah warga terutama pada daerah yang dekat dengan pantai dan pabrik. Sehingga jarak rumah satu dengan yang lain sangat pendek bahkan tidak ada jarak sama sekali. Dengan kerapatan jarak antar rumah yang seperti itu menyebabkan bahaya yang bias timbul tiba-tiba misalnya kebakaran, banjir dan sebagainya.

Bangunan rumah penduduk di kampung sejahtera tampak cukup padat. Tampak sejumlah bangunan rumah yang dindingnya saling menempel antara satu rumah dengan yang lain. Ada pula sejumlah bangunan rumah yang jarak antar dinding rumahnya hanya seberapa centimeter. Bagian depan rumah dipinggir jalan biasanya diberi pagar, sedangkan yang agak jauh dari jalan jarang yang memiliki pagar. Hal ini, antara lain agar lebih bebas atau lega karena ruang akibat sempitnya pekarangan. Sebagian rumah penduduk ini tidak memiliki halaman. Kalaupun ada, halaman itu relative sempit. Salah satu akibatnya, tempat bermain dan membuang sampah terasa kurang memadai.

\section{Kehidupan Nilai Masyarakat}

Kehidupan nilai masyarakat di kampung sejahtera ini tampak begitu tenang dan damai, walau menghadapi kehidupan di era globalisasi ini. Interaksi kehidupan sosial budaya dalam bertetangga terjalin erat dan saling membantu satu sama yang lainnya. Sikap saling membantu terwujud dalam bentuk gotong royong yang lebih mementingkan kehidupan bersama. Gotong royong yang terbentuk ketetanggaan misalnya dalam hajatan, kematian, pembuatan dan perbaikan rumah dan lain-lain. Sedangkan gotong royong yang bersifat umum misalnya perbaikan jalan, pembersihan gorong-gorong/siring serta pembersihan makam dan acara petik laut.

\section{Kehidupan Religi}

Penduduk kampung sejahtera dalam masalah agama sangat beragam yaitu agama islam, agama hindu, agama kristen. Diantara agama yang lainnya, Islam sebagai agama mayoritas, namun kehidupan umat beragama tetaplah harmonis. Hal ini terlihat belum ada kasus yang bertentangan dengan SARA. Dengan demikian pula peran ulama tampak lebih menonjol. Meskipun masyarakat kampung sejahtera memeluk agama Islam dengan taat, namun mereka tidak semuanya meninggalkan bentuk-bentuk kepercayaan lama. Jadi selalu muncul tata nilai dan tata laku yang berdasarkan kepercayaan lama yang telah berakar dan terjalin di daerah ini.

Masyarakat kampung sejahtera masih percaya makam keramat yaitu kuburan yang dikeramatkan oleh warga suatu wilayah karena diyakini dapat memberikan perlindungan dan berjasa kepada seluruh warga di wilayah itu. Roh leluhur penghuni makam biasanya merupakan tokoh masyarakat yang pada masa hidupnya dipandang mempunyai kesaktian dan banyak berjasa bagi kehidupan 
masyarakat. Mereka percaya pada kekuatan gaib terutama kekuatan yang berada pada benda- benda yang dianggap sakti dan keramat. Masyarakat sangat menghormati benda-benda peninggalan nenek moyang atau pusaka peninggalan leluhurnya. Seperti keris, tombak dan pedang pusaka yang dianggap memiliki kesaktian, juga makam para leluhur dianggap suci dan keramat sehingga harus kerap diziarahi.

\section{PENUTUP \\ Kesimpulan}

Pemerhati masalah pemberdayaan masyarakat sudah banyak. Hal ini dibuktikan dengan munculnya berbagai penelitian tentang pemberdayaan masyarakat, diantaranya adalah pemberdayaan perempuan (Astuti, 2012), pemberdayaan pasien (Subandi, 2010), pemberdayaan karyawan atau Marginal Man dalam perusahaan (Asgarsani dkk, 2013), pemberdayaan masyarakat miskin (Astuti, 2012), dan pemberdayaan lansia (Sa'adah, 2014). Namun tidak semua pemberdayaan berjalan sesuai yang diinginkan karena belum mengetahui kondisi lingkungan dan latar belakang masyarakat, maka pemberdayaan hanya berlangsung saat pelaksanaan saja dan tidak ada tindak lanjut untuk kegiatan berikutnya. Dalam arti bahwa pengembangan potensi yang ada di social budaya belum dioptimalkan, kecenderungan kegiatan hanya berpusat pada seremonial saja, belum ada kejelasan niatan dari pihak terkait. Sehingga persepsi yang timbul di masyarakat nelayan kampung sejahtera bila ada program pengembangan hanyalah bersifat temporal dan tidak ada kejelasan arahnya. Mekanisme seharusnya harus diidentifikasi dengan kegiatan yang senantiasa berlangsung dalam kegiatan masyarakat tersebut sehingga secara alamiah akan berjalan dengan alamiah juga hasilnya mengikuti kegiatan yang sudah ada dibandingkan membuat program baru dan mengarahkan lagi tujuan baru.

Gaya hidup merupakan karakteristik seseorang yang bias diamati dan yang menandai system nilai serta sikap terhadap diri sendiri dan lingkungan sosialnya. Dilingkungan masyarakat pesisir kampung sejahtera ketika panen ikan hasil tangkapannya bias mencapai berton-ton untuk sekali melaut sehingga pendapatan para nelayan kampung sejahtera akan naik dengan drastic dibandingkan hari biasanya. Kebiasaan masyarakat nelayan ketika musim ikan mereka seringkali membelanjakan pendapatannya untuk membeli barang-barang.

Kepemilikan barang-barang tersebut merupakan sumber utama dari kepuasaan yang dirasakan oleh nelayan pesisir. Perilaku konsumsi masyarakat nelayan terhadap barang yang dimilikinya bersifat matrelialistis. Keyakinan ini merupakan manifestasi dari tingkat dimana kepemilikan materi merupakan sumber utama dari kepuasan dan ketidakpuasan seseorang dalam hidupnya. Kepuasan tidak pernah difikirkan bahwa ketika barang tersebut akan dijual kembalikan mengalami penurunan harga sehingga mengalami kerugian.

Kemampuan perempuan pesisir kampung sejahtera ini relative rendah disbanding dengan perempuanperempuan diluar wilayah pesisir. Menurut kasi pemerintahan kecamatan kampung melayu, Fadholi, hanya 5-10\% masyarakat pesisir yang memiliki inisiatif untuk melanjutkan pendidikan anaknya kejenjang yang lebih tinggi. Hal ini juga sangat mempengaruhi pola piker dari masing-masing orang yang pada akhirnya berimbas pada pola perilaku kehidupan keseharian mereka. Ada anggapan dan pandangan tentang pendidikan bagi perempuan tidak perlu tinggi akan mempengaruhi factor perempuan tidak melanjutkan kejenjang berikutnya, 
maksimal sampai dengan SMA dengan pertimbangan sebagai perempuan tidak perlu sekolah tinggi-tinggi ujung-ujungnya sebagai ibu rumah tangga dan yang bekerja tetap suami. Pandangan ini sangat besar pengaruh keputusan keinginan sekolah dan ini member nilai yang kuat pada generasi perempuan muda sekarang.

Berdasarkan gambaran diatas, kesadaran pendidikan sangat kurang dan terjadi pernikahan dini. Perempuan pesisir masih berfikir bahwa tugas perempuan hanya sebagai ibu rumah tangga walau hal tersebut sebagai amanah yang melekat, namun kewajiban dalam membangun keluarga tetap menjadi tanggungjawab bersama dangan memahami dengan tugasnya masing-masing. Disisi lain, factor budaya konsumtif (ekonomi) dapat mempengaruhi tingkat partisipasi pendidikan. Jika kasus ini dibiarkan terlalu lama, maka pada akhirnya sikap dan mental dari masyarakat khususnya generasi perempuan pesisir akan sulit untuk dirubah.

Kemampuan seorang perempuan pesisir dalam beraktifitas akan menentukan besaran hasil yang didapatkan, begitu pula sebaliknya. Secara umum perempuan pesisir memiliki kemampuan atau skill yang relative rendah. Sebagai seorang istri nelayan, aktifitas yang dilakukan hanya sebatas melakukan transaksi jual beli secara manual, gelondongan, mentahan. Tidak ada inisiatif untuk mengolah ikan itu menjadisesuatu yang lebih mahal dari sekedar dijual mentahan yang seharusnya mendapatkan hasil berlipat. Hal ini dilakukan secara monoton dan terus menerus sesuai dengan tradisi yang telah ada dari para leluhurnya.

Kecamatan kampung melayu merupakan wilayah kecamatan terbesar dan memiliki salah satu pelabuhan perikanan penghasil produksi perikanan terbesar. Hasil tangkap ikan didominasi oleh beberapa jenis ikan laut. Sehingga kampung sejahtera yang berada di kecamatan kampung melayu merupakan daerah pelabuhan perikanan paling penting untuk beberapa jenis ikan. Dalam perkembangannya banyak perusahaan perikanan yang beroperasi di sekitar wilayah ini diantaranya industri pengalengan, cold storage, pemindangan, pengasinan, penepungan, dan industry pengolahan lainnya.

Memahami kondisi tarik dan ulur permasalahan maka ada baiknya pemangku kepentingan duduk bersama untuk melihat bersama dan mencermati bagaimana memetakan lagi nilai yang sudah ada dan dikembangkan sedangkan yang kurang perlu dirilis pengertian. Sarana edukasi perlu ditekankan lebih dominan karena perubahan yang paling dominan adalah merubah cara pandang tentang komitmen menjadi berdampak pada ekosistem kehidupan yang seimbang karena semua aktivitas bergantung pada alam maka manusia harus memahami kaedah alami.

\section{DAFTAR PUSTAKA}

Arbaiyah. 2011. Pemberdayaan Perempuan dalam Pembangunan Masyarakat Pesisir Pantai (Studi Pada Desa Kuala Lama Kecamatan Pantai Cermin Kabupaten Serdang Bedagai). Departemen Ilmu Administrasi Negara FISIP Universitas Sumatra Utara Medan. Skripsi

Bengen, D.G. 2001. Pengelolaan Sumberdaya Wilayah Pesisir Secara Terpadu, Berkelanjutan dan Berbasis Masyarakat. Bogor, Makalah pada Sosialisasi Pengelolaan Sumberdaya Berbasis Masyarakat.

Farihah, Irzum dan Sunyoto, Usman. 2002. Etos Kerja dan Pengambilan Keputusan Dalam Keluarga Nelayan. Yogyakarta, Universitas Gadjah Mada,.

Fraskho, Maria. 2000. Praktek dan Teori Pembangunan Ketergantungan. Jakarta, Analisis CSIS 
Harsoyo, E. Harmayani, A. Suryantini. 1999. Dampak Pembangunan Pertanian Terhadap Marginalisasi Tenaga Kerja Wanita : Kasus Usahatani Salak di Kabupaten Sleman. Jurnal Gender Vol (1) : 44

Hurlock, Elizabeth B. 1991. Psikologi Perkembangan: Suatu Pendekatan Sepanjang Rentang Kehidupan. Jakarta, Penerbit Erlangga

Illo, Jeanne Frances I. dan Jaime B. Polo. 1990. Fishers, Traders, Farmers, Wives. Manila: IPC Ateneo de Manila University.

Imam Prakoso. 2008. Alternatif Pemenfaatan TIK Bagi Keberdayaan Rakyat dan Pengentasan Kemiskinan. Jurnal Dialog Kebijakan Publik. Jakarta, Penerbit Kominfo

Kusnadi. 2007. Strategi Hidup Masyarakat Pesisir. Yogyakarta, LKIS

Keban, Yeremias T., dan Gabriel Lele. 1999. Capacity Building dalam Wacana Pembangunan Kontemporer : Telaah Konseptual dan Implikasinya. Yogyakarta, Tiara Wacana Yogya

Krisnawaty, Tati. 1993. Peluang Kerja Perempuan Miskin dan Strategi Survive, Dalam Dinamika Gerakan Perempuan di Indonesia. Yogyakarta, Tiara Wacana Yogya

Moleong. L. 2000. Metodelogi Penelitian Kualitatif. Jakarta, PT. Remaja Rosdakarya.

Nugraheni S, Wahyu, dkk. 2012. Peran dan Potensi Wanita Dalam Pemenuhan Kebutuhan Ekonomi Keluarga Nelayan. Jurnal studi Pendidikan Sosial Vol.1 No.2 Tahun 2012.

http://journal.unnes.ac.id/sju/index.ph p/jess. Diunduh pada tanggal 16 Juni 2016 at 12.34 WIB.
Nurwati, Nunung. 2008. Kemiskinan: Model Pengukuran, Permasalahan, dan Alternativ Penyelesaian. Jurnal Kependudukan Padjajaran, Vol 01 No. 01.

Pandu, Maria E, dkk. 2014. Potensi dan Pemberdayaan Perempuan Pesisir Dalam Meningkatkan Pendapatan Keluarga (Kasus Daerah Pesisir Bantaeng dan Sinjai). Jurnal elektronik ekososbudkum 466. http://repository.unhas.ac.id/handle/1 23456789/13858. Di unduh pada tanggal 16 Juni 2016 at 12.58 WIB.

Soetrisno, L. 1997. Kemiskinan, Perempuan, dan Pemberdayaan. Yogyakarta, Kanisius

Suranto. 2002. Gerakan Feminisme Dan Emansipasi Wanita. Jurnal Ilmu Pengetahuan Sosial Vol 3 No. Januari 2002. Jember, Jurusan Pendidikan Ilmu Pengetahuan sosial Universitas Jember.

Sutopo, H.B. 2006. Metode Penelitian Kualitatif Dasar Teori Dan Terapannya Dalam Penelitian. Surakarta, Uneversitas Sebelas Maret

Setyawati E, Yuningtyas. 2012. Pemberdayaan Perempuan Pesisir Melalui Pengembangan Manajemen Komoditas Perekonomian Berbasis Potensi Lokal (Studi Pemberdayaan Ekonomi Perempuan di Kawasan Pantai Kuwaru, Kecamatan Srandakan, Kabupaten Bantul, DIY). Yogyakarta, Laporan Penelitian LPPM Universitas Atma Jaya. Di Unduh pada tanggal 16 Juni 2016 at 12.26 WIB.

Warga, Richard D. 1983. Personal Awareness.. Boston, A Psychology of Adjustment. Houghton Mifflin Company 


\section{LAMPIRAN TABEL}

Tabel Indikator kependudukan di Kecamatan Kampung Sejahtera

\begin{tabular}{|l|c|c|c|}
\hline Indikator kependudukan & $\mathbf{2 0 1 3}$ & $\mathbf{2 0 1 4}$ & $\mathbf{2 0 1 5}$ \\
\hline Jumlah penduduk & 130.270 & 132,014 & 132.604 \\
\hline Luas wilayah & 76,9 & 76,9 & 76,9 \\
\hline Kepadatan penduduk & 1.694 & 1.694 & 1.724 \\
\hline Sex Ratio & 101,53 & 101,53 & 101,64 \\
\hline \% penduduk menurut umur & & & \\
\hline 0-14 Tahun (\%) & 23,85 & 23,85 & 24,17 \\
\hline 15-64 Tahun ( \% ) & 68,95 & 68,95 & 68,95 \\
\hline$>65$ Tahun (\%) & 7,11 & 7,11 & 7 \\
\hline
\end{tabular}

Sumber: Kec.Kampung Melayu, 2016 